This is a post-peer-review, pre-copyedit version of an article published in J Market Anal. The final authenticated version is available online at https://doi.org/10.1057/s41270-020-00080-w.

\title{
Establishing social media firestorm scale via large dataset media analytics
}

\begin{abstract}
A social media (SoMe) firestorm can present a liability for personal brands via the loss of reputation, as well as for the organisational brand image. The drastic measures often taken in these situations, especially in cases of negative media attention or a scandal, usually involve dismissal of the related persons. Hence, predicting, monitoring, analysing and measuring SoMe firestorms related to organisations or individuals can be beneficial. This paper describes SoMe firestorms and their effect, using media analysis involving opinion mining. The analysis focuses on the human trash (ihmisroska) scandal that was caused by a local centre party politician in Finland. The politician caused a SoMe firestorm by describing homeless people and substance addicts as 'human trash'. The analysis utilises machine learning to classify 3,300 media hits in the Finnish language to analyse their sentiment during the SoMe firestorm. General conclusions are drawn about the spread and influence of the SoMe firestorm to form a basis for wider global generalisation. The study formulates a scale for quantifying and analysing the influence of SoMe firestorms. The scale includes three classes relating to the exponential rise of the effect, starting from 1, with 3 being the highest. This scale aligns with the literature, which states that these events usually follow the same pattern. The case example provides further direction for the presented 1-3 level scale.
\end{abstract}




\section{Introduction}

A social media (SoMe) firestorm may erupt if a certain public statement or action angers people. The anger is spread virally through the social media, causing a firestorm of messages and media postings. As a result of questionable statements or actions, SoMe users can create fierce firestorms that represent a challenge for marketing communications (Pfeffer et al, 2014). A firestorm can be described as a scandal if norms have been broken, wrongdoings are committed, and the whole community is shaken (Dahlgren et al, 2011). Scandals also fuel the tabloid and newspaper sales of the editorial media, who also gather large amounts of readers to create online discussions (Dahlgren et $a l, 2011)$. Despite the existence of some related discussions, the extant literature has failed to provide a means for analysing or measuring the impact of SoMe firestorms.

This study focuses on the human trash scandal caused by a centre party politician in Finland who described homeless people and substance addicts as 'human trash' in a local council meeting. The scandal is analysed via algorithm-based media analysis to understand the dynamics of SoMe firestorms. Aside from utilising media monitoring algorithms, manual data validation is also carried out. Effectively, the rise of social media as an effective communications channel is discussed along the structure and influence of SoMe firestorms. A scale is formulated for measuring SoMe firestorms.

The paper organised as follows, first the related literature is reviewed, followed by the methodology. The data analysis and manual validation are then presented. Discussion and presentation of the scale devised for analysing SoMe firestorms are next, and finally the conclusions are stated.

\section{Social media platforms}

Social media (SoMe) involve a variety of services that allow users to communicate and interact with each other and share content (Helasvuo et al, 2014) The rise of SoMe has widened the scope of traditional journalism, taking it from being the purview of the privileged to becoming a civil right of general citizens (Heinonen and Domingo, 2009). In addition to creating content, SoMe allows for an increased distribution of information and is currently the primary information source for many of us (Westerman et al, 2013). Groups outside traditional media have also found a new channel of influence within SoMe (van Riel, 2013). SoMe is part of the media disruption, where the active role of the media participants is emphasised; each person with network access is able to express themselves and 
co-operate with others (Laaksonen et al, 2013). Compared to traditional media, SoMe includes more emotional content (Stieglitz and Dang-Xuan, 2013), and the language used in SoMe, referred to as digital discourse, highlights specific features of groups or individuals communicating in SoMe, or reflects selected language choices in selected contexts (Helasvuo et al, 2014).

\section{Social media firestorms}

The firestorm headlines in traditional editorial media can be divided into news headlines, reaction headlines, follow-up headlines or a combination of these; thus, there are always two issues that need to be in the headline: 1) someone did something and 2) a SoMe firestorm erupted (Nousiainen, 2017). The basic principle of media influence is that there is no need/reason to communicate without expected influence (Scheufele, 1999).

In cases of larger firestorms, the term scandal can be used. Thompson (2000) and Esser and Hartung (2004) define a scandal as a breaking of moral codes, misbehaviour and lack of respect towards one's values. An outsider recognises a misdemeanour, disapproves of it and publicly denounces the person. Usually the person is related to an elite group and is therefore supposed to behave better than so-called 'regular people'. In traditional news media, at least one media outlet needs to publish the news, after which others will follow. Nowadays, the news media will gladly also publish disapproval that is present on social media. The resulting scandal may negatively influence the personal brand of its subject and causing them to lose their reputation, usually leading to firing of the person. Consequently, the scandal becomes a means for maintaining social control and acts as sanction for misbehaviour (Dahlgren et al, 2011; Kantola and Vesa, 2011; Karvonen, 2011; Juntunen and Väliverronen, 2009).

An ill-advised statement or act by a leading person is a classical reason for an organisational crisis. A crisis situation develops in five stages: 1) latent stage, where weak signals of the upcoming crisis are received; 2) triggering event, where the subject becomes the target of news and SoMe attention; 3 ) the subject is in the top-news and the media attention spikes; 4) the media attention calms down to the level of general philosophical and ethical discussion; and 5) there are only minor media hits and attention is guided to other issues (Lehtonen, 1999). A similar cycle is depicted also by Anthony Downs (1972) (cited in Suhonen, 1994). The last stage of the Downs model includes a view that the discussion themes will remain, to some extent, in the 
general consciousness (Harju, 2019). The human trash case studied in this paper fits this scandal and crisis pattern. The subject was a well-paid CEO, leader and member of the political elite, who referred to homeless people and those suffering from substance abuse as 'human trash'. The whistle-blower, in this case, was a member of a populist party who who is well accustomed to creating tensions between normal citizens and elite leaders (Niemi, 2012). The human trash case allows for observation of both the occurrence of the media spike and the related consequences on a personal and corporate level.

\section{Method: Media analysis with automated sentiment analysis}

The method applied in this paper takes advantage of M-Adaptive software for media monitoring by utilising an algorithm-based sentiment classification that is aided by machine learning. The analysed sources cover 3 million social media platforms, 100,000 news outlets in 71 languages in 236 regions (M-Brain, 2015). The sentiment analysis is based on a combination of linguistic knowledge and human-aided machine learning, which means that the software makes suggestions for classifications to humans, and humans then provide feedback on the correctness. Via this procedure, the system learns to improve its classification of content into sentiment categories (M-Brain, 2015). A similar approach was studied in Nuortimo and Härkönen (2019); however, so far, algorithm-based research utilising sentiment classification has not been widely applied as a basis for organisational decision making. (Liu and Zhang, 2012).

The keyword used in this analysis was 'human trash' ('ihmisroska' in Finnish, loosely translated). The utilised software gained the necessary data by mining the wide sources of media. The obtained data were analysed by plotting the hits on a timeline and automatically classifying them as positive, negative, neutral and mixed. The study appeared to be particularly challenging for both algorithmbased classification and for human classification. The challenge was deciding whether when the incident is negative, are the following re-postings or re-tweets negative as well? For the purpose of this study, these cases were classified as neutral. Sarcasm and irony are also challenging for both human and algorithm-based classification. In addition, the magnitude of the analysed data is not possible for humans to process and is only possible to gain via algorithm-based analysis. The data were, however, validated by human review, including random testing of approximately $10 \%$ of the entire dataset. 
The following research questions were formulated to support the study:

RQ1: How did the scandal begin and advance in the human trash case?

RQ2: What was the content of the scandal based on the automated sentiment classification?

RQ3: What were the consequences of the scandal and how do these correlate with the literature?

RQ4: How can the results be generalised to form a classification for SoMe firestorms?

Questions 1-3 are related to the human trash firestorm, RQ4 relates to results generalisation and formulation of a SoMe firestorm scale. The research questions are answered in the discussion section.

Traditional content analysis has been carried out for a long time in media studies; however, the digitalisation megatrend has made it possible to utilise 'big data' involving a large number of hits from both social media and traditional news media (Lansdall-Welfare et al, 2017; Flaounas et al, 2010, 2011; Lampos et al, 2012; Cristianini, 2011). Hence, the use of big data sentiment analysis is increasing in SoMe analytics (Chaudhary, et al, 2018). In opinion mining/sentiment analysis, the media hits from editorial media and SoMe are automatically classified by algorithms into sentiment classes, such as positive, negative, neutral and mixed (Ahmed and Danti, 2015). This approach belongs to a wider context of computational linguistics, where sentiment analysis is one of the most important applications of text-analytics, aiming to extract information about the human emotional state (Do et al, 2019, Al-Smadi et al, 2019, Moraes et al, 2013).

The sentiment and quantitate analyses of media hits provide indication of a rising SoMe firestorm. This information can be used to guide issues in management, crisis and marketing communications functions of a company. According to the literature, large media spikes that rise fast should have the largest influence. In addition to SoMe, editorial content can also include subjective elements, which are visible in the analytics (Hillert et al, 2018). The approximate $20 \%$ error in the sentiment classification is present in all data series, thus the comparability of datasets remains. The machinebased content classification is based on manifest content more so than on latent content, for which a human classifier can be more sensitive (Berelson, 1952). Therefore, the implicit meanings are left outside the analysis. The next section presents the findings of the human trash case. 
Due to the nature of the study, it is appropriate to also mention the philosophical side. This study combines the philosophical streams of positivism and interpretivism. What is regarded as appropriate knowledge about the social world is a concern of epistemology. The question over whether a natural science model of the research process is suitable for studying the social world is a vital aspect (Bryman and Bell 2007). A central issue is the question of whether the social world can, and should be, studied according to the same principles, procedures and philosophy as the natural sciences (Saunders 2007). It may not be possible to precisely outline what the concepts of positivism and interpretivism mean within the context of social media use, but a question of whether the phenomena can be measured would be one possibility for considering whether the epistemology is positivist. The media analytics allow for measuring of the social media in a thermometer-like manner, which would imply positivism. Interpretivism contrasts with positivism, holding the view that people are fundamentally different from the view offered by the natural sciences. The logic of an interpretivist research procedure must hence be completely different when studying the social world; it should reflect the distinctiveness of humans against the natural order (Saunders 2007). Hence, both philosophical streams are involved; the media analytics allow for measurement of social media engagement in a thermometer-like manner, which implies positivism, but the creation of a 3-point scale implies a level of interpretivism.

\section{SoMe firestorm data analysis - The human trash case}

Although the selected case presents a rather local example of a SoMe firestorm, which focuses on media hits in the Finnish language, it is viable for analysis that uses limited computational power. The case was selected for the following reasons: 1) the term 'human trash' was presented for the first time, and the media hits are concentrated on this incident;2) the case presents an extreme challenge to automated sentiment classification algorithms, thus the resulting SoMe commentary was versatile and presented a lot of sarcastic and ironic comments; 3) the case represents a link between media attention and tangible action taken at the corporate level, thus providing additional info on media influence; and 4) with the help of this case and the algorithm-based approach, the comparable scale created for SoMe firestorms could follow a similar pattern to scales created for earthquakes and hurricanes. 
The human trash case is a scandal that started in a city council meeting of Oulu, Finland on the evening of September 10, 2018, when the centre party politician Ms Riikka Moilanen described marginalised people, homeless people and substance abusers as 'human trash' during a discussion related to the littering and existence of an abundance of rubbish in the city centre. She raised a question, stating, '...but what are we going to do with this human trash?' This motivated a political opponent, Mr Sebastian Tynkkynen of true Finns, to post the video on Facebook on the same night. The post caused so much social media attention that as a result, within the next 24 hours, Ms Moilanen was laid off from her position of CEO at Pihlajanlinna (Finnish health service provider). Figure 1 illustrates the timeline of the related media attention.

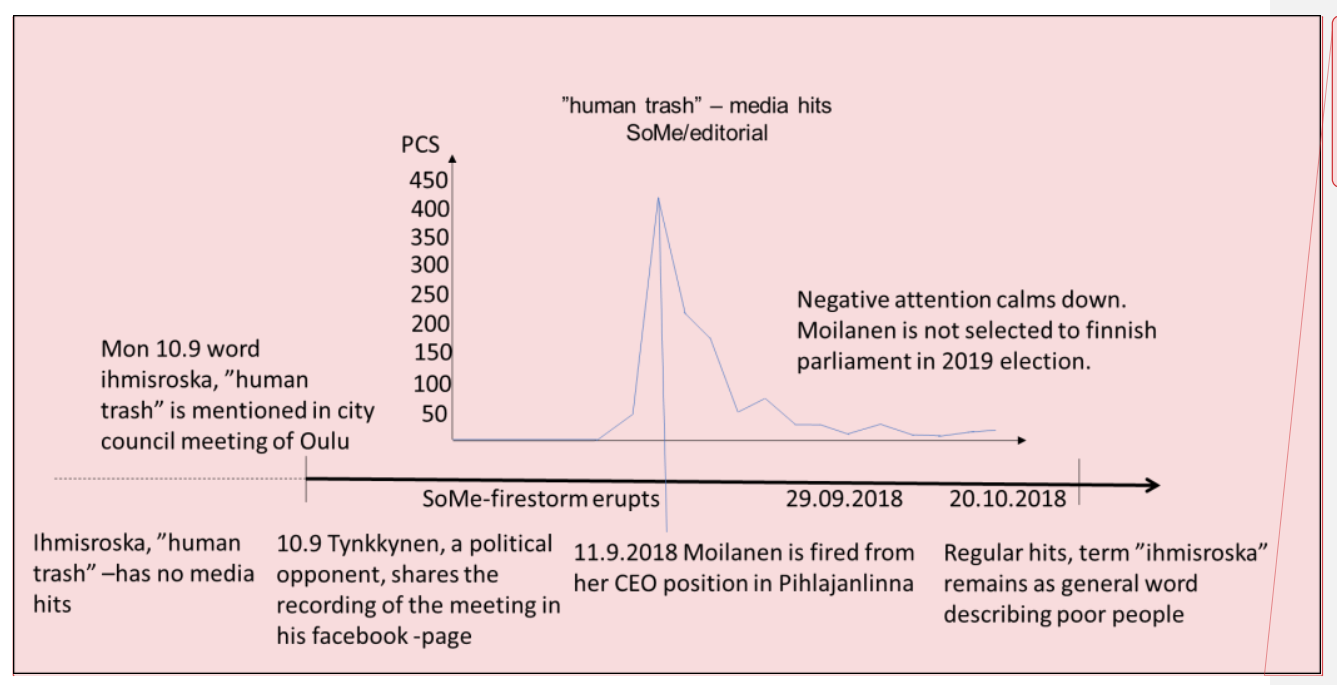

Commented [.1]: Note: Single quotation marks should be used for British English. Facebook should also be capitalized and no hyphen between FB and page. There should also be a space after the en-dash (bottom left corner of the diagram).

Figure 1. Human trash case on a timeline with media attention, both in editorial media and SoMe

The media analysis was carried out during the time period of July 1, 2018 to March 31, 2019, resulting in 3,330 hits from both editorial content and social media. The dataset included Finnish language hits. Figure 2 illustrates the results of the sentiment analysis carried out for the data during the analysis period. In particular, negative hits from discussion forums are emphasised in the findings (almost 1,000 hits), and it is notable that positive hits comprised only half of the amount of the negative hits. The scandal was clearly negative. The results show how a relatively small number of hits in the media can result in drastic measures being taken. 
If looking at individual sources, on Twitter, neutral re-tweets were emphasised (300) and there were fewer negative hits (approx. 150). In the editorial media, there were 150 neutral and 50 mixed hits, whereas the negative and positive hits were almost equal (approx. 250). Blogs and Facebook had fewer hits in total.

Ihmisroska , "human trash" sentiment analysis from

\subsubsection{8-31.3.2019}

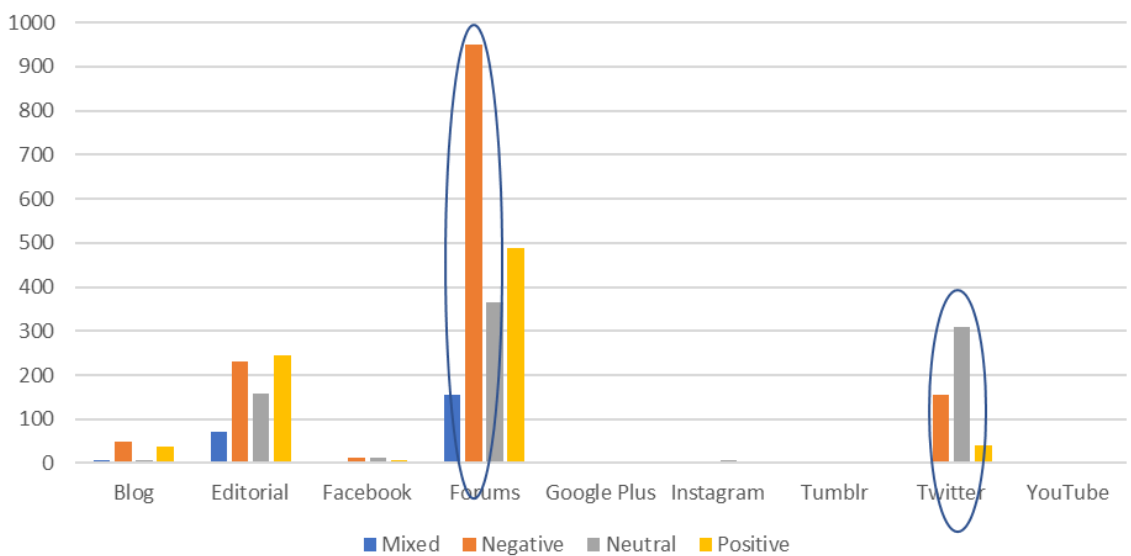

Figure 2. Human trash case - sentiment analysis

\section{Method validation - Human trash case}

The method used in this paper, media analysis based on commercial software with intellectual property rights protected algorithms, can only be validated by human inspection. This was done in the human trash case. The 3,330 hits focused on a fairly narrow time frame, offering the possibility for human inspection. The case itself presented a challenge for the automated classification due to there being an exceptionally large proportion of sarcasm and irony involved. This case can be considered as the most difficult case type for sentiment classification algorithms to handle.

The data validation was made as follows:
Commented [.2]: Again, note that single quotation marks should be used in British English. 
1) Hits were included in a single table

2) There was one classification for the algorithm and two human classifiers

3) Reviewer 1 was fast and checked mainly the shorter hits, reviewer 2 was thorough and checked longer texts

4) The reasons for classification failure were stated in the notes sections

5) An indication was provided for whether the hit concerned this particular case.

The main results of the data validation are summarised in Table 1.

Table 1. Results of data validation

\begin{tabular}{lll}
\hline & Reviewer 1 & Reviewer 2 \\
\hline Reviewed hits & 298 & 68 \\
Correct \% & $81 \%$ & $52 \%$ \\
Combined accuracy & $243 / 328=74 \%$ & \\
Overlapping hits & 34 & \\
All three (one machine \& two humans) agree & 12 & \\
All three (one machine \& two humans) disagree & 4 & \\
\hline
\end{tabular}

The two reviewers selected 328 points (34 overlapping) from the total 3,330 datapoints to carry out data validation. The resulting $74 \%$ accuracy makes it possible to analyse how the firestorm escalates based on quantities/sentiments, and also to compare it to other firestorms. The error in sentiment classification is similar in all data series. The gained overall accuracy of $74 \%$ correlates with the internal test results of the software supplier.

It is possible to discover main themes of discussion from the content analysis, including those suggested by Freudian slip or through references to other similar scandals. One feature was a generalisation of the subject, including: 1) The politician who called addicts and homeless in Oulu city centre 'human trash'; 2) The values and view of the centre party, elite and Pihlajanlinna company (Finnish health service provider) against marginalised and poor people; and 3) Arrogant elite vs. regular people. The conversation shifted rapidly away from the individual politician, and already at the time of her discharge as CEO, there were scholars commenting in the media. During the following week, there were also analyses from consultants. 
When comparing the machine-based sentiment analysis to human analysis, it is to be noted, that human classification is not $100 \%$ correct either; people do not all understand irony, sarcasm or passive-aggressive statements in a similar manner. This was also seen in the analysis of this case. In this case, the overlapping datapoints from three cases, machine, human 1 and human 2, had similar results for all three of these types of statements in 12 cases out of 34 . In four cases, all three disagreed. Human classifier 1 calculated that approximately $10 \%$ were difficult to determine whether they were neutral or negative, so the accuracy result would be closer to $70 \%$ if these were to be classified otherwise. Longer texts were thoroughly evaluated by human classifier 2 on negative and neutral hits, and the related machine-based classification was approximately $63 \%$ correct; with positive hits, only $9 \%$ were correct due to their sarcasm, irony and latent content.

After the media attention had calmed down in March 2019, the 11-hit test indicated the absence of connections between the politician in relation to the search word, and other issues became linked to the term 'human trash'. As a result of the scandal, the term became a new word in Finnish vocabulary. Table 2 presents the classification differences, in the form of loose translations from Finnish language, illustrating the SoMe hits during the media spike on September 10, 2018. 
Table 2. Examples of content and automatic classification

\begin{tabular}{|c|c|c|c|}
\hline $\begin{array}{l}\text { Media hit (translated from } \\
\text { Finnish) }\end{array}$ & Source/time & $\begin{array}{l}\text { Sentiment by human } \\
\text { classification }\end{array}$ & $\begin{array}{l}\text { Sentiment by algorithm } \\
\text { classification/ } \\
\text { Right }(\mathbf{R}) / W r o n g(W) \\
\end{array}$ \\
\hline $\begin{array}{l}\text { Scandal: Ex-central party } \\
\text { politician referred to } \\
\text { marginalised people in Oulu } \\
\text { city centre as 'human trash'. }\end{array}$ & Twitter/10.9.2018 & Neutral & Neutral/R \\
\hline $\begin{array}{l}\text { I hope that your children end } \\
\text { up to being like these human } \\
\text { trash. }\end{array}$ & $\begin{array}{l}\text { Suomi24 discussion } \\
\text { forum/10.9.2018 }\end{array}$ & Negative & Negative/R \\
\hline $\begin{array}{l}\text { Human trash !!!? You can't } \\
\text { say that of anyone, } \\
\text { especially as a representative } \\
\text { of city of Oulu and a } \\
\text { company. }\end{array}$ & $\begin{array}{l}\text { Kaleva newspaper } \\
\text { discussion } \\
\text { forum/10.9.2018 }\end{array}$ & Negative burst & Negative/R \\
\hline $\begin{array}{l}\text { I would not call anyone } \\
\text { human trash. }\end{array}$ & Twitter 10.9.2018 & $\begin{array}{l}\text { Passive- } \\
\text { aggressive/leaning } \\
\text { towards negative }\end{array}$ & Neutral/R \\
\hline $\begin{array}{l}\text { The only human trash in } \\
\text { Oulu is you. }\end{array}$ & Twitter/10.9.2018 & $\begin{array}{l}\text { Passive-aggressive, } \\
\text { intimidating }\end{array}$ & Positive/W \\
\hline $\begin{array}{l}\text { The CEO of Pori jazz was } \\
\text { kicked of due to same } \\
\text { reason. How's } \\
\text { @Pihlajalinna, 'human trash' } \\
\text { is not a good business? }\end{array}$ & Twitter/10.9.2018 & Sarcastic & Positive/W \\
\hline $\begin{array}{l}\text { Did Riikka Moilanen (centre } \\
\text { party) accidentally reveal her } \\
\text { true thoughts. She is the } \\
\text { CEO of Pihlajanlinna. }\end{array}$ & Facebook/10.9.2018 & $\begin{array}{l}\text { Suggests Freudian slip } \rightarrow \\
\text { will she reveal her true } \\
\text { thoughts }\end{array}$ & Positive/W \\
\hline $\begin{array}{l}\text { Pihlajanlinna will help Finns } \\
\text { for better life, unless you are } \\
\text { human trash? }\end{array}$ & Twitter 10.9.2018 & Sarcastic & $\begin{array}{l}\text { Positive, classification } \\
\text { comes from sentence: helps } \\
\text { Finns for better life/W }\end{array}$ \\
\hline $\begin{array}{l}\text { @ centre party calls } \\
\text { marginalised people human } \\
\text { trash, 'ihmisroskaksi'. great } \\
\text { \#centre party great. }\end{array}$ & Twitter 10.9.2018 & Sarcastic & $\begin{array}{l}\text { Positive, Classification is } \\
\text { influenced by great, great./ } \\
\text { W }\end{array}$ \\
\hline $\begin{array}{l}\text { Luckily centre party makes } \\
\text { everything to remove human } \\
\text { trash 'ihmisroskan' from our } \\
\text { society. }\end{array}$ & Twitter 10.9.2018 & Sarcastic & Positive./W \\
\hline $\begin{array}{l}\text { I consider myself to be more } \\
\text { biowaste than human trash, } \\
\text { but that's just semantics. }\end{array}$ & Twitter 10.9.2018 & Ironic & Neutral/W or $\mathrm{R}$ \\
\hline $\begin{array}{l}\text { If you call others human } \\
\text { trash, you do not belong to a } \\
\text { leadership position of any } \\
\text { credible company. }\end{array}$ & Twitter 10.9.2019 & Passive-aggressive & Neutral/W \\
\hline
\end{tabular}

It is visible from the comments in Table 2 that the human trash case instigated an unusual amount of sarcastic and ironic commenting, as well as comments with latent meanings, which presented a challenge for automated classification. This was visible from the positive comments, which were in this case, mostly error classifications. 


\section{Discussion: towards the general SoMe firestorm scale}

Forming the basis of SoMe firestorm scale

Because the media scanning algorithms are objective and they always classify the sentiments in a similar manner, the influence of the media spike of a SoMe firestorm can, to some extent, be standardised. However, regarding this point, due to a lack of extensive statistical correlation analysis, this does not suggest direct causality; instead, it mainly highlights increased probability. This would follow similar logic to the Richter scale for earthquakes or the Saffir-Simpson scale for hurricane rating, where the approximate magnitude of the event is scaled, but information about where exactly the phenomenon is going to hit or whose house will be damaged is not available. Nevertheless, also in these cases, if some kind of early warning is received, it is possible to plan counter-actions in the case of the event. This approach is also supported by the fact that SoMe firestorms usually follow the pattern presented as illustrated in Figure 3. This was the situation in the human trash case and reflects what has also been described in the literature. The rating would follow a similar logic to, for example, the 5-level Saffir-Simpson classification for hurricanes; however, in this case, it has an approximate $24 \%$ error margin due to the limitations of sentiment classification.

The results from this study can also be generalised to other SoMe firestorms. Based on the data, a 'SoMe firestorm scale' can be developed to highlight the scale and influence of the firestorm. This idea of a standardised rating is presented as Figure 3. 


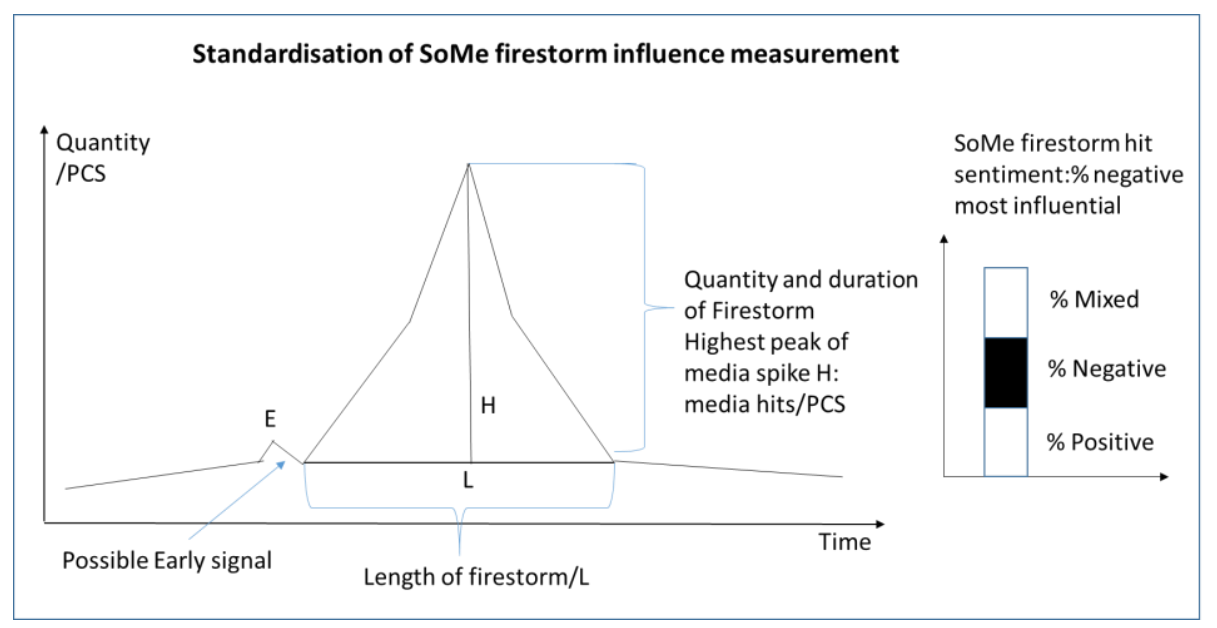

Figure 3. Standardisation of SoMe firestorm measurement

This rating would include the height of the resulted SoMe spike $(\mathbf{H})$, length of the storm $(\mathbf{L})$, and also the \% of negative hits in the storm.

\section{Simplified formula for suggested Nuortimo SoMe firestorm scale:}

$\mathbf{H}$ (number of Hits in media spike/PCS) * $\mathbf{L}$ (length of firestorm/days) * $\%$ negative SoMe hits

Level 1 SoMe firestorm = Minimum influence: Local. Dissipates fast with minor influence on concrete level. Small height of spike (hundreds of hits), small length, mostly mixed or low \% negative hits.

Level 2 SoMe firestorm = Moderate influence: Mostly local but with a wider spread than in level 1. Heated discussion lasts several days (some thousands or tens of thousands, spike height some hundreds/thousands). Large influence on local level. Large portion of \% negative media hits.

Level 3 SoMe firestorm = Extensive influence: Global scandal (over 100,000 hits in total, spike height several thousands) with maximum effect. Large masses posting negative and heated content. Large international consequences. International scandal.

This approach would, in practice, give a numerical rating for the SoMe firestorm, such as those offered in the following examples (Table 3 ). 
Table 3. Numerical examples of SoMe firestorm classification

\begin{tabular}{|l|l|l|l|l|}
\hline $\begin{array}{l}\text { Numerical } \\
\text { example }\end{array}$ & $\begin{array}{l}\text { No of hits in } \\
\text { spike/pcs(H) }\end{array}$ & $\begin{array}{l}\text { Length of the } \\
\text { intensive } \\
\text { firestorm/days } \\
\text { (L) }\end{array}$ & $\begin{array}{l}\text { \% negative } \\
\text { hits in } \\
\text { firestorm }\end{array}$ & $\begin{array}{l}\text { Example result } \\
\text { of rating }\end{array}$ \\
\hline Level 1 storm & 150 & 2 & $30 \%$ & $\mathbf{9 0}$ \\
\hline $\begin{array}{l}\text { Level 2 storm } \\
\text { (based on human } \\
\text { trash } \text { case) }\end{array}$ & 420 & 30 & $42 \%$ & $\mathbf{5 , 2 9 2}$ \\
\hline Level 3 Storm & 10000 & 60 & $70 \%$ & $\mathbf{4 2 0 , 0 0 0}$ \\
\hline
\end{tabular}

The suggested numerical scale would be exponential in level and influence of the SoMe firestorm, where level 1 storm would involve some hundreds, level two some thousands or tens of thousands, and level 3 some hundreds of thousands and more. The suggested scale can be refined with further data analysis, but is at any rate, logically extrapolated from the example case and matches the pattern shown in the literature.

The benefits of this type of scaling come from: 1) The possibility to take advantage of early signals E in Figure 3 to guide corporate actions towards incoming firestorm; 2) In general, individual/corporate actions can be guided towards dealing with incoming scandal, depending on its rating. The larger the firestorm is, the more efforts required from corporations and/or individuals. If someone has a personal level 1 firestorm arising, it might not need any other action than a simple apology, whereas for a level 3 hurricane that is spreading globally and which may have international with consequences or potential for wars or other major incidents more significant action will be needed. Suggested organisational actions in case of different scale SoMe firestorms are presented in Table 4. 
Table 4. Example actions related to SoMe firestorm level

\begin{tabular}{|l|l|l|l|l|}
\hline $\begin{array}{l}\text { Level of } \\
\text { storm }\end{array}$ & $\begin{array}{l}\text { Organisations } \\
\text { involved in large } \\
\text { company }\end{array}$ & $\begin{array}{l}\text { Possible } \\
\text { internal actions }\end{array}$ & $\begin{array}{l}\text { Possible } \\
\text { external action }\end{array}$ & Example result \\
\hline Level 1 storm & $\begin{array}{l}\text { Communications/crisis } \\
\text { communication }\end{array}$ & $\begin{array}{l}\text { Internal } \\
\text { discussions }\end{array}$ & $\begin{array}{l}\text { Minor, apologies } \\
\text { in SoMe or } \\
\text { elsewhere }\end{array}$ & $\begin{array}{l}\text { Internal limited } \\
\text { discussions }\end{array}$ \\
\hline Level 2 storm & $\begin{array}{l}\text { Communications, } \\
\text { marketing } \\
\text { communications, } \\
\text { middle management }\end{array}$ & Intra release & Press release & $\begin{array}{l}\text { Internal and } \\
\text { external } \\
\text { communication } \\
\text { to stakeholders }\end{array}$ \\
\hline Level 3 Storm & $\begin{array}{l}\text { All organisation } \\
\text { levels, including CEO }\end{array}$ & $\begin{array}{l}\text { Internal \& } \\
\text { external } \\
\text { communication, } \\
\text { possible changes } \\
\text { in organisation, } \\
\text { etc. }\end{array}$ & $\begin{array}{l}\text { Communications } \\
\text { and marketing } \\
\text { communications } \\
\text { campaigns to } \\
\text { mitigate risks } \\
\text { related to brand } \\
\text { image, etc. }\end{array}$ & $\begin{array}{l}\text { Organisational } \\
\text { changes, changes } \\
\text { in company } \\
\text { structure and } \\
\text { policies, legal } \\
\text { actions, etc. }\end{array}$ \\
\hline
\end{tabular}

The research questions can be answered as follows:

A1: The human trash scandal followed the path known from the literature. It was followed by an organisational action: the CEO was sacked.

A2: The scandal was visible in media analytics as a large negative SoMe spike, which calmed down rather quickly. Afterwards the term 'human trash' was used in general contexts.

A3: The good features of analytics in the human trash case involve speed and potential to detect escalation. The challenges include accuracy of sentiment classification. The analytics make it possible to compare and analyse global data series.

A4: The results can be generalised globally, to a certain extent, from the human trash case to SoMe firestorm measurement and scaling. In order for a firestorm to be influential, a large quantity of negative SoMe hits are required, usually forming a spike in the analytics. The storm also needs to spread widely, and usually for a long time to reach the maximum consequences. For individuals and organisations, some type of early warning system for counteraction and mitigation would be needed to 1) try to evaluate possible effects of a SoMe firestorm in relation to its scale, and 2) try to mitigate the possible effects of a SoMe firestorm both for individuals and organisations, and also 3) try to prevent the firestorms from erupting by educating organisations and individuals about their behaviour, and forming organisational structures for scanning and launching necessary actions. 
Answers 1-3 are related to the human trash firestorm case; A4 relates to results generalisation and formulations of the SoMe firestorm scale.

\section{Limitations}

The limitations of this study include the methodology of analysing the dynamics of social media firestorm by the means of media analysis using a computational application to obtain the data. The focus was limited to analysing the scandal in question, and other perspectives such as potential support for the person causing the scandal are left outside the scope of this study. In addition, the distribution of opinions among the population is not under focus, but the dynamics of a scandal that can be created by badly formulating words in public. The study does not take into account any potential cultural factors that might exist elsewhere, a factor that limits the generalisability. Even analysing a scandal caused by the use of the same term might result in different findings elsewhere. Additionally, because the analysed term has variable meanings or can be used in completely different contexts, the analysis may be more challenging and could influence the results. This study does not take a stand on social politics in any form but utilises the term 'human trash' as an example due to its characteristics which allow for measuring and linking it to concrete actions. Some other terms might be more complex to measure in other contexts.

\section{Conclusion}

This paper presents a general social media firestorm measurement scale derived from analysing the human trash case, where a local politician, who was also CEO of a company, caused a scandal by referring to addicts and homeless people as 'human trash'. This type of exponential scale can be used to describe the level of effects of SoMe firestorms. The study attempts to clarify how social media firestorms follow the well-known patterns of scandals. It was possible to connect the scandal created by the politician's unfortunate choice of wording to concrete actions. The case had clearly marked boundaries, and most importantly, it could be measured. The case was chosen as exemplary due to the term human trash not having multiple meanings in the language of analysis at the time of the study. The study follows a dualistic philosophical stream in the sense that the applied media analytics allow measurement of the social media response in a thermometer-like manner, implying positivism, 
but the presented social media firestorm standardisation and the presented 3-point scale would imply a level of interpretivism.

The novel contribution of this study is its introduction of a scale for measuring social media firestorms by applying media analytics. The firestorm scale can help with determining the size and potential impact of the firestorm. The implications of this research involve being able to understand the dynamics of social media firestorms. The ability to predict, monitor, analyse and measure social media firestorms may help with protecting both the personal brands of individuals and the reputations of organisations. Understanding the dynamics of social media firestorms and being able to prepare for necessary counter-actions may benefit the area of marketing analytics and communications.

Further studies are needed to refine the scale and to undertake further case analytics, globally or regionally. In addition, further studies are needed to better understand the necessary organisational counter-actions in cases of different scales of social media firestorms. The results from the human trash case correspond to the crisis communication literature and also present linkage to political science; thus, the scandal can be considered as an act of a political opponent, an aspect that also requires further study. 


\section{Conflict of interest}

On behalf of all the authors, the corresponding author states that there are no conflicts of interest.

\section{References}

Al-Smadi, M., Talafha, B., Al-Ayyoub, M. and Jararweh, Y. (2019) Using long short-term memory deep neural networks for aspect-based sentiment analysis of Arabic reviews. International Journal of Machine Learning and Cybernetics 10(8): 2163-2175.

Ahmed, S. and Danti, A. (2015) A novel approach for sentimental analysis and opinion mining based on SentiWordNet using web data. Paper presented at the 2015 International Conference on Trends in Automation, Communications and Computing Technology (I-TACT-15); 21-22 December, Bangalore, India.

Berelson, B. (1952) Content Analysis in Communication Research. Michigan: Free Press.

Bryman, A., and Bell, E. (2007) Business research methods. 2nd edition. Oxford University.

Press.Chaudhary, M., Kumar, H., Kaushal, S. and Sangaiah, A.K. (2018) The case analysis on sentiment based ranking of nodes in social media space. Multimedia Tools and Applications 77(4): 4217-4236.

Cristianini, N. (2011) Automatic discovery of patterns in media content. In: R. Giancarlo and G. Manzini (eds.) Combinatorial Pattern Matching. CPM 2011. Lecture Notes in Computer Science, vol 6661. Berlin, Heidelberg: Springer.

Dahlgren, S., Kivistö, S. and Paasonen, S. (2011) Johdanto: skandaalin maisema. In: S. Dahlgren, S. Kivistö and S. Paasonen (eds.) Skandaali! Suomalaisen taiteen ja politiikan mediakohut Porvoo: Bookwell Oy, pp. 7-17.

Do, H.H., Prasad, P.W.C., Maag, A. and Alsadoon, A. (2019) Deep learning for aspect-based sentiment analysis: A comparative review. Expert Systems with Applications 118, 272-299.

Downs, A. (1972) Up and down with ecology: The issue-attention cycle. Public Interest 28, 38-50.

Esser, F. and Hartung, U. (2004) Nazis, pollution and no sex. Political scandals as a reflection of political culture in Germany. American Behavioral Scientist 47(8): 1040-1071.

Flaounas, I., Turchi, M., Omar, A., Fyson, N., De Bie, T., Mosdell, N., Lewis, J. and Cristianini, N. (2010) The structure of the EU mediasphere. PLoS ONE 5(12): e14243.

Flaounas, I., Omar, A., Turchi, M., Snowsill, T., Nicart, F., De Bie, T. and Cristianini, N. (2011) NOAM: News outlets analysis and monitoring system. Proceedings of the 2011 ACM SIGMOD International Conference on Management of Data.

Harju, Aki (2019) Pohjoisen kaivokset suomalaisissa sanomalehdissä. Acta Universitatis Ouluensis. B, Humaniora 170. http://urn.fi/urn:isbn:9789526221748

Heinonen, A. and Domingo, D. (2009). Blogit journalismin muutoksen merkkinä. In: E. Väliverronen (ed.), Journalismi murroksessa. Helsinki: Hakapaino, pp. 68-87. 
Helasvuo, M-L., Johansson, M. and Tanskanen, S-K. (2014). Johdatus digitaaliseen vuorovaikutukseen. In: M-L. Helasvuo, M. Johansson and S-K. Tanskanen (eds.) Kieli verkossa näkökulmia digitaaliseen vuorovaikutukseen. Vantaa: Hansaprint Oy, pp. 9-28.

Hillert, A., Jacobs, H. and Müller, S. (2018) Journalist disagreement. Journal of Financial Markets, 41(November): 57-76.

Juntunen, L. and Väliverronen, E. (2009) Intiimin politiikka ja skandaalin yhteiskunnallinen merkitys. In: E. Väliverronen (ed.): Journalismi murroksessa. Helsinki: Gaudeamus, pp. 262-284.

Kantola, A. and Vesa, J. (2011) Skandaalit ja julkinen elämä Suomessa. In: A. Kantola (ed.). Hetken hallitsijat. Julkinen elämä notkeassa yhteiskunnassa. Helsinki: Gaudeamus.

Karvonen, E. (2011) Julkkispoliitikko median suurennuslasissa. In: A. Koivunen and M. Lehtonen (eds.) Kuinka meitä kutsutaan? Kulttuuriset merkityskamppailut nyky-Suomessa. Tampere: Vastapaino, pp. 187-218.

Laaksonen, S-M., Matikainen, J. and Tikka, M. (2013) Tutkimusotteita verkosta. In: S-M. Laaksonen, J. Matikainen and M. Tikka (eds.) Otteita verkosta. Tampere: Vastapaino, pp. 9-33.

Lampos, V. and N. Cristianini. (2012). Nowcasting events from the social web with statistical learning. ACM Transactions on Intelligent Systems and Technology (TIST) archive 3(4): Article 72.

Lansdall-Welfare, T., Sudhahar, S., Thompson, J., Lewis, J.; FindMyPast Newspaper Team and Cristianini, N. (2017) Content analysis of 150 years of British periodicals. Proceedings of the National Academy of Sciences January 2017 114(4): E457-E465. doi:10.1073/pnas.1606380114

Lehtonen, J. (1999). Kriisiviestintä. Helsinki: Mainostajien liitto.

Learning. ACM Transactions on Intelligent Systems and Technology (TIST) 3(4): 72.

Liu, B. and Zhang, L. (2012) A survey of opinion mining and sentiment analysis. Mining Text Data. New York: Springer.

M-Brain, corporate communications, received 11/2015.

Moraes, R., Valiati, J.F. and Neto, W.P.G. (2013) Document-level sentiment classification: An empirical comparison between SVM and ANN. Expert Systems with Applications 40(2): 621-633.

Niemi, M.K. (2012) Timo Soini perussuomalaisen identiteetin isäntänä. In: V. Pernaa and E. Railo (eds.) Jytky. Eduskuntavaalien 2011 mediajulkisuus. Kirja Aurora. Turun Yliopisto, pp. 324-349.

Nousiainen, A. (2017) Somekohun anatomia. Eli miten somekohut ja somekohuotsikot rakentuvat. Master's thesis, Department of Language and Communication Studies. University of Jyväskylä.

Nuortimo, K. and Harkonen, J. (2019) Establishing an automated brand index based on opinion mining: Analysis of printed and social media. Journal of Marketing Analytics 7(3): 141-151.

Pfeffer, J., Zorbach, T., and Carley, K.M. (2014) Understanding online firestorms: Negative wordof-mouth dynamics in social media networks. Journal of Marketing Communications, 20(1-2): $117-128$.

Saunders, M., Lewis, P., and Thornhill, A. (2007) Research methods for Business Students. 4th ed., Prentice Hall.

Scheufele, D. (1999) Framing as a theory of media effects. Journal of Communication 49(1): 103122. 
Stieglitz, S. and Dang-Xuan, L. (2013) Emotions and information diffusion in social mediaSentiment of microblogs and sharing behavior. Journal of Management Information Systems 29(4), 217-248.

Suhonen, P. (1994) Mediat, me ja ympäristö. Helsinki: Hanki ja jää.

Thompson, J.B. (2000) Political Scandal. Power and Visibility in the Media Age. Cambridge: Polity Press.

van Riel, C.B.M. (2013) Corporate reputation and the discipline of public opinion. In: C.E. Carrol (ed.) The Handbook of Communication and Corporate Reputation. Chichester, UK: Wiley-Blackwell, John Wiley \& Sons.

Westerman, D., Spence, P.R. and Van Den Heide, B. (2013) Social media as information source: Recency of updates and credibility of information. Journal of Computer-Mediated Communication 19(2): 171-183. 